Tersedia online di: http://ejournal-balitbang.kkp.go.id/index.php/JP
e-mail.jurnalpari@gmail.com
JURNAL PARI
Volume 3 Nomor 2 Desember 2017
p-ISSN: 2502-0730
e-ISSN : 2549-0133

\title{
PENGELOLAAN KOLEKSI LOCAL CONTENT DI PERPUSTAKAAN KHUSUS INSTANSI PEMERINTAH: STUDI KASUS DI PERPUSTAKAAN KEMENTERIAN KELAUTAN DAN PERIKANAN
}

\begin{abstract}
PAMELA DAMAYANTI
Biro Kerja Sama dan Hubungan Masyarakat, Sekretariat Jenderal

Diterima tanggal : 20 September 2017 diterima setelah perbaikan : 27 Oktober 2017 disetujui terbit : 5 Desember 2017

ABSTRAK

Keberadaan informasi local content merupakan hal yang penting karena dapat menunjukkan identitas dan jati diri dari sebuah entitas lokal, termasuk instansi pemerintah. Perpustakaan menjadi salah satu wadah bagi koleksi local content KKP untuk kemudian dapat terwujud pusat informasi kelautan dan perikanan. Kajian ini bertujuan untuk mengetahui bagaimana pengelolaan koleksi local content di Perpustakaan KKP, mulai dari proses penghimpunan, pengelolaan, hingga pendayagunaan serta hambatan-hambatan dalam pelaksanaannya. Metode deskriptif digunakan dalam kajian yang bersifat dasar (basic research) ini untuk mengetahui sejauh mana keberlangsungan pengelolaan koleksi local content di Perpustakaan KKP. Pengumpulan data dilakukan dengan cara observasi dan studi dokumen terkait perpustakaan khusus serta pengelolaan koleksi local content. Hingga saat ini, masih terdapat hambatan dalam pengelolaan koleksi local content di Perpustakaan KKP, khususnya pada proses penghimpunannya. Kurangnya koordinasi dan partisipasi dari seluruh staf/ anggota KKP serta belum adanya peraturan yang rinci dan jelas mengenai penghimpunan koleksi local content menjadi penyebab pengelolaan koleksi local content di Perpustakaan KKP belum berjalan sebagaimana mestinya.
\end{abstract}

Kata Kunci: local content, perpustakaan khusus, Perpustakaan KKP, pengelolaan koleksi

\begin{abstract}
Local content plays an important role of government institution because it shows uniqueness and identity of local entity. Library is one of a place for managing local content, and so is Perpustakaan KKP, towards Knowledge Repository of Perpustakaan KKP for building marine and fisheries knowledge. This study is intended to understand the management of local content in Perpustakaan KKP, starts from collecting, organizing end with providing the access of it. And also to identify the challenges as well as the benefits. This study is a basic research using descriptive methode and data is gathered by observation and document study of special library, local content and collection management. It shows that establishing a regulation related with the process of collecting local content published by Kementerian Kelautan dan Perikanan needs to be addressed in the future.
\end{abstract}

Keywords : local content, special library, Perpustakaan KKP, collection management

Korespondesi penulis:

Perpustakaan KKP, GMB IV lantai 2 jl. Medan Merdeka Timur No.16 10110

email : pamela@kkp.go.id 


\section{PENDAHULUAN}

Perpustakaan Kementerian Kelautan dan Perikanan (yang selanjutnya disebut Perpustakaan KKP) adalah perpustakaan khusus di bawah Kementerian/Lembaga dengan sebagian besar koleksinya adalah mengenai subyek kelautan, perikanan dan maritim. Perpustakaan KKP, sesuai dengan PERMEN KP Nomor 8 Tahun 2014, memiliki tugas pembinaan terhadap Perpustakaan pada Unit Kerja Eselon I dan Perpustakaan UPT di lingkup KKP. Oleh karena itu, guna memaksimalkan pemanfaatan seluruh koleksi terbitan KKP, atau yang selanjutnya disebut dengan local content, seluruh Perpustakaan Unit Kerja Eselon I dan UPT wajib menyerahkan koleksi local content yang dimiliki kepada Perpustakaan KKP.

Sesuai dengan Peraturan Pemerintah Republik Indonesia Nomor 24 Tahun 2014 tentang Pelaksanaan UU Nomor 43 Tahun 2007 tentang Perpustakaan, yang disebut local content atau ketika dialihbahasakan ke dalam Bahasa Indonesia menjadi muatan lokal adalah jenis koleksi yang merupakan terbitan internal dan/ atau koleksi tentang daerah. Dalam hal ini, local content pada Perpustakaan KKP adalah koleksi yang diterbitkan oleh atau dari Kementerian Kelautan dan Perikanan. Local content ini dapat menjadi sebuah brand dari institusi atau lembaga yang menaungi perpustakaan itu sendiri. Di berbagai institusi, utamanya di bidang pendidikan, local content telah menjadi promosi dari potensi koleksi yang dimiliki institusi. Seperti contoh Library Automation and Digital Archive (LONTAR) dari Universitas Indonesia dan Indonesian Capital Market Electronic Library (ICaMEL) dari Bursa Efek Indonesia.

Di sisi lain, melalui local content, Perpustakaan KKP diharapkan dapat menjadi pusat pengetahuan kelautan dan perikanan yang dapat menunjang kebutuhan informasi pengguna, khususnya para pelaku di bidang kelautan dan perikanan. Yang mana tujuan tersebut telah tertuang dalam tagline Perpustakaan KKP melalui poyek knowledge repository, yaitu "Building Maritime Knowledge." Namun, hingga saat ini hal tersebut belum dapat terlaksana dengan baik. Salah bentuk indikasinya adalah masih sulitnya penghimpunan koleksi local content dari seluruh Unit Kerja Eselon I lingkup KKP. Begitupun dengan teknis penyerahan dan pengelolaan dari koleksi local content itu sendiri, khususnya yang berbentuk digital atau soft copy, belum berjalan sesuai ketentuan yang ditetapkan. Untuk itu, diperlukan manajemen pengelolaan koleksi local content yang baik untuk dapat menjadikan Perpustakaan KKP sebagai pusat informasi dan pengetahuan mengenai subyek kelautan dan perikanan.

Berdasarkan latar belakang yang telah disebutkan, maka kajian ini memfokuskan pada bagaimana pengelolaan koleksi local content di Perpustakaan KKP, mulai dari kegiatan penghimpunan, pengolahan dan pelayanan koleksi. Tanpa disadari, koleksi local content merupakan sebuah rekaman dan warisan dari suatu institusi yang hanya dimiliki oleh institusi itu sendiri. Untuk itu, koleksi local content tersebut perlu dikelola secara baik sehingga dapat dimanfaatkan masyarakat secara luas sehingga transfer pengetahuan dapat terjadi serta sebagai upaya pelestarian dari karyakarya intelektual yang disimpan.

\section{TINJAUAN LITERATUR PERPUSTAKAAN KHUSUS}

\section{Perpustakaan Khusus}

Menurut Mobley dan Ferguson (1984: 4), perpustakaan khusus adalah suatu unit atau departemen dari satu organisasi/institusi dimana fungsi utamanya adalah melakukan pelayanan guna memenuhi kebutuhan informasi para staf atau anggota pada organisasi/institusi yang dinaunginya.

Dari pengertian di atas dapat dikatakan bahwa perpustakaan khusus memiliki koleksi yang berbeda antara satu organisasi dengan organisasi lainnya. Hal ini disebabkan oleh kebutuhan informasi dari setiap anggota organisasi juga berbeda disesuaikan dengan tugas pokok dan fungsi dari organisasi yang menjadi induk dari perpustakaan khusus tersebut.

Totterdell dan Harrison (2000: 23) mengemukakan bahwa selain dari keunikan koleksinya, perpustakaan khusus juga memiliki klasifikasi pengguna tersendiri. Dalam hal ini, pelayanan informasi dari perpustakaan khusus hanya ditujukan kepada staf atau anggota dari suatu organisasi/institusi dengan tujuan mendukung staf atau anggota tersebut dalam menyelesaikan tugas dan pekerjaan secara lebih efektif dan efisien. 


\section{Koleksi Local Content}

Pada seminar/lokakarya nasional mengenai perubahan paradigma di bidang informasi yang diselenggarakan di Universitas Petra, SulistyoBasuki (2001) menyampaikan bahwa local content adalah buku atau cantuman tertulis lainnya yang berkaitan dengan sebuah kawasan geografis yang diterbitkan oleh sebuah badan korporasi atau perorangan, baik yang tersedia di toko buku maupun yang berbentuk literatur kelabu (grey literature) .

Liauw (2007:2) mengemukakan bahwa local content adalah sumber informasi yang memiliki entitas lokal dan diproduksi hanya secara lokal atau tidak melalui jalur penerbitan komersil. Local content juga merupakan dokumentasi dari aktivitas lembaga itu sendiri dalam bentuk data mengenai kegiatan, hasil pekerjaan maupun kegiatankegiatan intelektual yang sedang berlangsung.

Dari definisi-definisi yang di atas, dapat disimpulkan bahwa local content adalah sumber informasi yang berbentuk karya cetak maupun karya rekam yang memuat sumber informasi dari tiap-tiap kegiatan maupun hasil pekerjaan yang dihasilkan oleh suatu lembaga, biasanya tidak diterbitkan secara luas, dan dapat dimanfaatkan sebagai sumber pembelajaran (learning resources).

Koleksi local content dapat berasal dari karya cetak dan karya rekam yang memiliki informasi yang bermanfaat. Setiawati (2006:2) menjelaskan bahwa potensi local content dapat berupa :

1. potensi suatu daerah/negara salah satunya kebudayaan, sejarah, pariwisata, perekonomian dan sebagainya, yang menjadi ciri khas dari suatu daerah/negara;

2. potensi local content perusahaan salah satunya sejarah perusahaan, perkembangan produk yang dihasilkan dan dokumentasi suatu media;

3. potensi local institusi pendidikan atau perguruan tinggi yang terdiri para akademisi, peneliti, tenaga non edukatif sebagai pengguna informasi pengetahuan aktif yang menghasilkan riset penelitian, skripsi, tugas akhir, laporan akhir, artikel ilmiah, materi kuliah, kumpulan kebijakan pimpinan perguruan tinggi, sejarah perguruan tinggi atau event-event yang dilaksanakan oleh institusi/perguruan tinggi yang didokumentasikan baik tercetak maupun terekam;
4. potensi lainnya yang dihasilkan oleh para profesional.

Dari penjelasan tersebut dapat disimpulkan bahwa koleksi local content dapat berupa potensi yang memiliki manfaat dan relevan dengan kebutuhan informasi dari suatu masyarakat di daerah tertentu. Local content ini dapat menjadi dapat dijadikan sebagai salah satu warisan dari suatu daerah, masyarakat, atau institusi karena mengandung informasi entitas lokal dari unsurunsur tersebut.

\section{Pengelolaan Koleksi Local Content}

Menurut Jhonson (2010:2), pengelolaan koleksi adalah sebuah proses informasi mulai dari perencanaan, perumusan kebijakan, pengumpulan, komunikasi, koordinasi serta evaluasi. Proses ini dapat berpengaruh kepada keputusan tentang pemusnahan, pengadaan dan akses terhadap sumber informasi yang ada untuk mendukung kebutuhan informasi dari pengguna.

Adapun menurut Dictionary for Library and Information Science (2004), pengelolaan koleksi adalah kegiatan perencanaan dan pengawasan dari perkembangan serta pemeliharaan koleksi perpustakaan yang berdasarkan pada tinjauan kekuatan dan kelemahan yang ada disertai dengan perkiraan kebutuhan pengguna di masa yang akan datang.

Dari kedua pengertian tersebut dapat disimpulkan bahwa pengelolaan koleksi perpustakaan merupakan suatu proses kegiatan dimulai dari perencanaan yang dituangkan dalam perumusan sebuah kebijakan pengelolaan koleksi, penghimpunan koleksi serta pelayanan koleksi dimana koleksi tersebut dikomunikasikan kepada pengguna. Kemudian pemeliharaan koleksi yang mencakup pengawasan dan evaluasi dari koleksi yang terdapat di perpustakaan. Adapun kegiatankegiatan tersebut disesuaikan dengan kekuatan dan kelemahan dari perpustakaan sehingga kebutuhan informasi pengguna di masa yang akan datang dapat dikaji.

\section{METODE PENELITIAN}

Kajian ini merupakan kajian dasar (basic research)menggunakan metode penelitian deskriptif guna menggambarkan serta mengobservasi pengelolaan koleksi local content di Perpustakaan KKP. Kegiatan pengumpulan data dalam kajian 
ini dilakukan dengan studi dokumen yang terkait dengan pengelolaan koleksi perpustakaan khusus dan observasi terkait pelaksanannya. Adapun observasi yang dilakukan dari Bulan Mei hingga Bulan Desember 2016 adalah observasi yang bersifat partisipatif. Observasi dilakukan dengan tahapan yaitu melakukan pengamatan terhadap perkembangan proyek knowledge repository kemudian mengevaluasi pengelolaan koleksi local content di Perpustakaan KKP.

\section{PEMBAHASAN}

\section{Perpustakaan KKP}

Perpustakaan KKP merupakan perpustakaan khusus yang berada di bawah institusi pemerintah Kementerian Kelautan dan Perikanan. Perpustakaan KKP berdiri sejak tahun 2006 dan berada di bawah Pusat Data Statistik dan Informasi, Sekretariat Jenderal, KKP. Kemudian pada Desember 2015, sesuai dengan PERMEN KP Nomor 23 Tahun 2015 tentang Organisasi dan Tata Kerja Kementerian Kelautan dan Perikanan, Perpustakaan KKP berada di Subbagian Hubungan Lembaga dan Publikasi, Bagian Hubungan Masyarakat, Biro Kerja Sama dan Hubungan Masyarakat, Sekretariat Jenderal, KKP.

\section{Fungsi Perpustakaan KKP}

Fungsi dari Perpustakaan KKP sesuai dengan PERMEN KP Nomor 8 Tahun 2014 tentang Pedoman Penyelenggaraan Perpustakaan Khusus di Lingkungan Kementerian Kelautan dan Perikanan adalah sebagai berikut.

a. penyebaran informasi kelautan dan perikanan;

b. koordinasi antar perpustakaan khusus di lingkungan Kementerian;

c. pusat dokumentasi skripsi, tesis dan disertasi yang dilakukan oleh pegawai Kementerian yang telah menyelesaikan tugas belajar dan izin belajar, baik tercetak maupun elektronik;

d. pusat dokumentasi karya tulis/kertas kerja hasil pendidikan dan pelatihan yang dilakukan oleh pegawai Kementerian, baik berupa bahan cetak maupun elektronik;

e. pusat dokumentasi hasil-hasil karya tulis ilmiah seperti jurnal, prosiding, buletin ilmiah, karya tulis ilmiah populer, maupun karya tulis populer terbitan Kementerian, baik berupa bahan tercetak maupun elektronik.
Adapun fungsi-fungsi tersebut diterapkan untuk mendukung peranan Perpustakaan KKP dalam mewujudkan misinya sebagai penunjang kegiatan dari institusi yang dinaunginya yaitu Kementerian Kelautan dan Perikanan untuk membangun sektor kelautan dan perikanan di Indonesia.

\section{Pengelolaan Koleksi Local Content di Perpustakaan KKP}

Dalam melaksanakan fungsinya, Perpustakaan KKP melakukan pengelolaan koleksi yang erat kaitannya dengan cara pengadaan, pengolahan dan pendayagunaan koleksi. Menurut Trinil (2008: 71), pengadaan koleksi dapat dilakukan dengan cara yaitu pembelian, tukar menukar, hadiah, serta menerbitkan sendiri. Pada dasarnya, Perpustakaan KKP melakukan pengadaan koleksi melalui tiga cara yaitu pembelian, hadiah dari unit kerja lingkup KKP maupun instansi/lembaga mitra dari KKP dan menerbitkan sendiri. Pengadaan koleksi perpustakaan dengan cara pembelian ini telah diatur dalam Rencana Kerja Anggaran Kementerian Lembaga (RKAKL). Adapun cara pengadaan melalui pembelian, terakhir dilakukan oleh KKP pada tahun 2015. Untuk tahun 2016 dan tahun 2017 pengadaan koleksi dengan cara pembelian seluruhnya dilakukan dengan cara by request atau dilakukan atas permintaan pimpinan. Koleksi-koleksi yang dibeli tersebut memiliki subjek kelautan dan perikanan atau terkait dengan tokoh Menteri Kelautan dan Perikanan, Susi Pudjiastuti. Dengan ketiadaan anggaran untuk melakukan pengadaan koleksi melalui pembelian pada dua tahun terakhir, yaitu pada tahun 2015 dan 2016, Perpustakaan KKP berusaha melakukan pengembangan koleksi melalui cara hadiah.

Untuk pengadaan melalui hadiah, khususnya koleksi terkait kelautan dan perikanan, Perpustakaan KKP melaksanakannya melalui cara penghimpunan dari seluruh unit kerja lingkup KKP, baik yang diterbitkan oleh unit kerja lingkup KKP maupun oleh staf dari unit kerja lingkup KKP. Adapun di KKP sendiri terdapat 9 (sembilan) unit kerja Eselon I yaitu Sekretariat Jenderal, Inspektorat Jenderal, Direktorat Jenderal Perikanan Tangkap (DJPT), Direktorat Jenderal Perikanan Budidaya (DJPB), Direktorat Jenderal Pengelolaan Ruang Laut (DJPRL), 
Direktorat Jenderal Penguatan Daya Saing Produk Kelautan dan Perikanan (DJPDSPKP), Direktorat Jenderal Pengawasan Sumber Daya Kelautan dan Perikanan (DJPSDKP), Badan Riset Sumber Daya Manusia Kelautan dan Perikanan (BRSDMKP) dan Badan Karantina Ikan, Pengendalian Mutu dan Keamanan Hasil Perikanan (BKIPM). Koleksi yang dihimpun antara lain berupa buku teks, jurnal, profil, koleksi referensi, peraturan perundang-undangan, statistik, prosiding, bahan rapat kerja, laporan yang meliputi laporan kegiatan, laporan tahunan, laporan bulanan dan laporan penelitian, kliping, ensiklopedi, tugas akhir yang meliputi skripsi, tesis dan disertasi, kebijakan, pedoman, direktori, pidato, peta, panduan, serta bacaan anak.

Selain dari unit kerja lingkup KKP, Perpustakaan KKP juga melakukan pengadaan dengan cara menerima hadiah melalui lembagalembaga lain yang menjadi stakeholder di bidang kelautan dan perikanan, di antara lainnya adalah BAKAMLA (Badan Keamanan Laut), BPS (Badan Pusat Statistik), LIPI (Lembaga IImu Pengetahuan Indonesia), BMKG (Badan Meteorologi dan Geofisika) serta penerbit-penerbit yang sering menerbitkan koleksi dengan subyek kelautan dan perikanan contohnya Penerbit KIARA (Koalisi Rakyat Untuk Keadilan Perikanan) dan Penerbit MPN (Masyarakat Perikanan Nusantara). Adapun untuk koleksi yang diadakan dengan cara hibah dari lembaga-lembaga lain, sebagian besar hanya berjumlah satu eksemplar. Untuk itu, Perpustakaan KKP menggandakan koleksi-koleksi tersebut dengan cara difotokopi sebanyak empat eksemplar sesuai dengan peraturan pelayanan koleksi di Perpustakaan KKP, yaitu empat eksemplar.

Adapun pengadaan dengan cara menerbitkan sendiri, Perpustakaan KKP melakukan penerbitan melalui unit kerja Eselon II yang menaunginya, yaitu dulunya melalui Pusat Data, Statistik dan Informasi (Pusdatin KP) serta saat ini melalui Biro Kerja Sama dan Humas untuk sebagai unit kerja induk dari Perpustakaan KKP. Sebagian besar koleksi yang diterbitkan sendiri adalah berbentuk statistik, kumpulan foto, kliping, laporan tahunan, laporan bulanan, laporan kegiatan, laporan kegiatan yang terkait dengan DPR, kebijakan dan buku teks. Namun, untuk saat ini di Biro Kerja Sama dan Humas, penerbitan koleksi perpustakaan banyak yang tidak dilakukan kembali, sebagai contoh adalah statistik, karena bukan merupakan tugas pokok dan fungsi dari unit kerja Eselon II yang menanungi Perpustakaan KKP.

Dari penjelasan pengadaan koleksi tersebut menunjukkan bahwa Perpustakaan KKP lebih memprioritaskan kepada penghimpunan koleksi local content. Selain untuk menyiasati keterbatasan anggaran pengadaan koleksi perpustakaan, hal tersebut dilakukan guna mencapai salah satu tujuan dari Perpustakaan KKP yaitu sebagai pusat informasi dan pengetahuan mengenai kelautan dan perikanan di Indonesia dalam rangka mendukung misi dari KKP yaitu pembangunan kelautan dan perikanan yang berdaya saing dan berkelanjutan untuk kesejahteraan masyarakat. Selain itu, koleksi local content di Perpustakaan KKP juga dapat menunjukkan identitas atau ciri khas dari organisasi KKP dengan memiliki koleksi yang memuat subyek kelautan dan perikanan. Hal ini sebagaimana tercantum dalam PERMEN KP Nomor 8 Tahun 2014 yang menyatakan bahwa Perpustakaan KKP memiliki fungsi sebagai pusat dokumentasi skripsi, tesis, disertasi, karya tulis/kertas kerja hasil pendidikan dan pelatihan, jurnal, prosiding, buletin ilmiah, karya tulis ilmiah populer, baik yang berupa bahan tercetak maupun elektronik dari seluruh lingkup KKP. Sehingga dengan ketersediaan koleksi local content di Perpustakaan KKP dapat menjadi keunikan dan kebanggan tersendiri bagi organisasi KKP yang dapat didayagunakan oleh masyarakat luas khususnya stakeholder di bidang kelautan dan perikanan.

Koleksi local content di Perpustakaan KKP sendiri berdasarkan data yang didapat dari aplikasi pengelolaan perpustakaan adalah sebanyak 1817 judul dari 4486 judul koleksi keseluruhan yang sebagian besar merupakan buku teks dan jurnal. Koleksi perpustakaan pada awalnya hanya terdiri dari koleksi tercetak. Hingga pada tahun 2015, Perpustakaan KKP melalui Pusat Data, Statistik dan Informasi KP (Pusdatin KP) menginisiasi pembuatan knowledge repository untuk mengakomodir seluruh terbitan dari dan oleh KKP yang berbentuk digital sehingga dapat dihimpun dan dilayankan oleh Perpustakaan KKP secara lebih luas kepada masyarakat.

Proyek knowledge repository Perpustakaan KKP dimulai pada tanggal 1 Oktober 2015 dan berakhir pada 2 Februari 2016. Gagasan proyek ini adalah dalam rangka memenuhi kebutuhan akan pengetahuan implisit dan eksplisit mengenai koleksi local content Perpustakaan KKP yang dapat diakses pada laman http://perpustakaan. 
kkp.go.id/kr/. Proyek ini diawali dengan pelatihan singkat bagi tenaga ahli perpustakaan mengenai sejarah singkat dan koleksi Perpustakaan KKP. Kemudian, tenaga ahli perpustakaan mendapat pelatihan mengenai langkah-langkah klasifikasi koleksi berdasarkan sistem Universal Decimal Classification (UDC).

Pada pelaksanaannya, melalui proyek ini Perpustakaan KKP menghimpun local content dari seluruh unit kerja di KKP yang berbentuk file digital untuk dapat diakses melalui laman web kapan saja dan dimana saja. Setelah koleksi perpustakaan dihimpun, dilakukan pengolahan terhadap koleksi-koleksi tersebut oleh pustakawan di Perpustakaan KKP melalui sistem manajemen perpustakaan SLiMS (Senayan Library Management System). Untuk klasifikasi dan nomor panggil, Perpustakaan KKP mengacu pada peraturan Universal Decimal Classification (UDC).

Selain penghimpunan koleksi local content dalam bentuk digital atau soft copy dalam rangka mendukung proyek knowledge repository, Perpustakaan KKP juga menghimpun koleksi local content dalam bentuk fisik. Pada Bulan Mei 2016, Perpustakaan KKP mengikuti sosialiasi yang diadakan oleh Perpustakaan Nasional RI terkait Serah Simpan Karya Cetak dan Karya Rekam lingkup Kementerian/Lembaga. Secara tidak langsung kegiatan tersebut mendukung Perpustakaan KKP dalam proses penghimpunan koleksi local content karena dapat digunakan sebagai dasar hukum yang kuat. Sesuai dengan peraturan yang dikeluarkan oleh Perpustakaan Nasional RI, Karya Cetak dan Karya Rekam dari sebuah Kementerian/Lembaga setiap judulnya harus diserahkan kepada Perpustakaan Nasional sejumlah 2 eksemplar, Perpustakaan Umum Daerah sejumlah 1 eksemplar serta Perpustakaan Khusus dari institusi yang menaunginya sejumlah kebijakan masing-masing perpustakaan khusus. Dimana peraturan di Perpustakaan KKP sebenarnya mengharuskan setiap judul dari koleksi local content diserahkan ke Perpustakaan KKP sejumlah 4 eksemplar. Namun, disebabkan oleh penyetakan dari satu judul local content KKP yang terbatas, maka unit kerja atau individu yang menghasilkan karya cetak dan karya rekam hanya perlu menyerahkan minimal satu eksemplar per satu judul kepada Perpustakaan KKP.

\section{Evaluasi Pengelolaan Koleksi Local Content di Perpustakaan KKP}

Dalam pengelolaan koleksi, pendayagunaan koleksi menjadi hal yang perlu diperhatikan karena bersinggungan langsung dengan pengguna perpustakaan. Di Perpustakaan KKP, telah digagas proyek knowledge repository sebagai sarana dalam mempermudah pendayagunaan koleksi local content oleh perpustakaan untuk pengguna perpustakaan. Namun, proyek ini masih memiliki peluang dan tantangan yang harus dihadapi dalam misi Perpustakaan KKP untuk mendiseminasikan informasi mengenai kelautan dan perikanan kepada masyarakat luas, khususnya para stakeholder di bidang kelautan dan perikanan.

Menurut Cullen dan Chawner (2011) dalam Mary Wu (2015), pada perpustakaan perguruan tinggi yang telah menggagas knowledge repository, partisipasi dari anggota atau staf institusi tersebut hanya $15 \%$ hingga $30 \%$ dalam pengumpulan karya intelektual mereka. Sebagian besar, proyek knowledge repository berada di perpustakaan yang berada pada unit kerja kecil dalam suatu institusi, sehingga manajer atau pustakawan kurang mendapat akses dan kuasa dalam proses akuisisi atau pengadaan koleksi local content (Xia \& Opperman, 2010). Selain itu, isu ketersediaan dana, teknologi dan sumber daya manusia juga masih menjadi tantangan, khususnya pada institusi-institusi yang kecil (Wren, Mueller \& Shellhase, 2009).

Di Perpustakaan KKP sendiri, penghimpunan koleksi local content dari seluruh unit kerja Eselon I KKP masih berlangsung dari Bulan Mei 2016 hingga akhir tahun 2016. Targetnya, seluruh koleksi local content KKP, diprioritaskan yang dalam bentuk digital, diterima oleh Perpustakaan KKP untuk kemudian diunggah ke halaman web knowledge repository. Diawali dengan mengirim Nota Dinas dari Biro Kerja Sama dan Humas mengenai permohonan pendataan koleksi local content yang terdapat di tiap-tiap unit kerja Eselon I kepada seluruh Eselon I lingkup KKP disertai dengan informasi kebijakan pengumpulan Karya Cetak dan Karya Rekam dari Perpustakaan Nasional RI. Kemudian, unit kerja Eselon I lingkup KKP menyerahkan koleksi dalam bentuk tercetak maupun digital kepada Perpustakaan KKP. Selain itu, penghimpunan koleksi local content juga dilakukan dengan cara mengirim 
surat pemberitahuan secara pribadi kepada staf KKP yang menghasilkan karya intelektual melalui electronic mail maupun yang berkunjung ke perpustakaan.

Sampai saat ini, koleksi local content yang terhimpun di Perpustakaan KKP adalah sejumlah 1817 judul tercetak dan 401 judul berbentuk digital. Ketika diputuskan untuk melakukan proyek knowledge repository, menurut Earwage (2008), penghimpunan dan pengelolaan local content sudah pasti membutuhkan kolaborasi antara pustakawan, ITspecialistsertapemangkukebijakan dari suatu organisasi. Dorothea Solo (2007) mengemukakan bahwa knowledge repository yang dibangun tidak akan berjalan dengan baik jika tidak ada keinginan dan ketertarikan dari seluruh staf atau anggota organisasi untuk ikut mengelola keberlangsungannya dengan salah satu caranya adalah memanfaatkan kontennya.

Tantangan tersebut juga ditemui di Perpustakaan KKP dalam pengelolaan koleksi local content. Proyek knowledge repository sendiri telah memiliki konsep yang mumpuni. Terlihat pada grand design yang ditunjukkan oleh diagram di bawah ini.

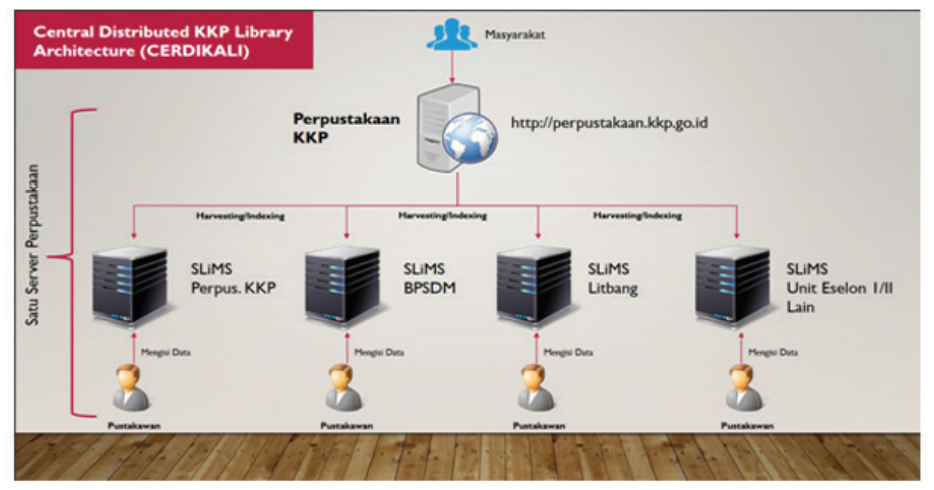

Gambar I. Central Distributed KKP Library Architecture (CERDIKALI)

Dari grand design di atas terlihat bahwa pengelolaan koleksi local content bersifat independen atau setiap Eselon I memiliki aplikasi pengelolaan perpustakaan tersendiri untuk mengunggah koleksi, terutama local content, serta seluruhnya terpasang dalam satu server di Perpustakaan KKP bersama dengan laman knowledge repository. Konsep grand design tersebut juga didukung oleh SOP terkait kata kunci yang harus diinput untuk kemudian koleksi local content dapat ditampilkan di laman knowledge repository.

Namun, konsep grand design tersebut belum dapat berjalan sesuai dengan yang diharapkan, yaitu sebagai database dari seluruh koleksi local content Kementerian Kelautan dan Perikanan. Hambatan yang tidak didukung oleh pemeliharaan yang berkelanjutan, terutama terkait ketersediaan perangkat keras dan perangkat lunak sebagai pendukung proyek knowledge repository. Matinya salah satu software pendukung yaitu elastic search yang berbasis Java dan adanya salah satu fitur pada Operating System yang kurang kompatibel menyebabkan terjadinya kerusakan (error) pada knowledge repository. Selain itu, kapasitas memori perlu ditingkatkan karena saat ini membutuhkan space yang lebih besar dalam rangka penghimpunan koleksi local content dalam bentuk digital.

Hambatan lain dalam penghimpunan koleksi local content KKP, baik bentuk fisik dan digital, adalah kurangnya koordinasi dari seluruh unit kerja Eselon I KKP sehingga partisipasi dalam proses penghimpunan koleksi local content menjadi rendah. Seringkali koleksi yang dihasilkan atau diterbitkan oleh UPT tidak terdata di pusat dan sebaliknya. Hal ini tentu saja menyulitkan Perpustakaan KKP sebagai unit yang memiliki tugas dan fungsi menghimpun koleksi local content.

Sejalan dengan kondisi tersebut, Van Earwage (2008) mengemukakan bahwa tanpa keinginan dan ketertarikan dari keseluruhan staf/anggota institusi, maka tidak akan terwujud proyek knowledge repository yang berkelanjutan. Adapun kurangnya partisipasi dan koordinasi tersebut disebabkan oleh beberapa faktor. Yang pertama adalah kurangnya kepercayaan diri dari staf/anggota terhadap karya mereka sendiri. Faktor kedua adalah anggapan bahwa jika sebuah karya disebarluaskan melalui knowledge repository, maka nilai (value) dari karya tersebut akan semakin menurun. Untuk itu, diperlukan dasar hukum melalui peraturan yang baku terkait penghimpunan koleksi local content dari sebuah institusi.

Peraturan sebagai dasar hukum untuk melakukan penghimpunan koleksi local content di Perpustakaan KKP memang pada dasarnya belum sepenuhnya rinci dan jelas. Selama ini Perpustakaan KKP menggunakan PERMEN 
KP Nomor KP Nomor 8 Tahun 2014 tentang Pedoman Penyelenggaraan Perpustakaan Khusus di Lingkungan Kementerian Kelautan dan Perikanan serta UU Nomor 4 Tahun 1990 tentang Serah Simpan Karya Cetak dan Karya Rekam. Tidak seperti di institusi pendidikan yang memiliki peraturan yang jelas dan rinci terkait pengumpulan koleksi local content dari Dirjen Dikti melalui Surat Edaran No. 152 E/T/2012 tentang Wajib Publikasi IImiah bagi S1/S2/S3, sehingga anggota institusi merasa berkewajiban untuk menyerahkan karya mereka ke perpustakaan.

Hal yang dapat dilakukan oleh Perpustakaan KKP adalah membuat peraturan mengenai wajib serah simpan karya yang dihasilkan oleh institusi KKP sendiri sebagai syarat sebelum pengajuan ISBN. Dimana peraturan tersebut dapat menyediakan data yang akurat mengenai koleksi local content, digunakan sebagai alat deteksi adanya plagiarisme, serta media promosi kepada masyarakat luas.

\section{KESIMPULAN}

Berdasarkan pembahasan di atas, kesimpulan yang dapat diambil adalah Perpustakaan KKP pada dasarnya telah melaksanakan pengelolaan koleksi local content yaitu mulai dari penghimpunan, pengolahan dan pendayagunaan koleksi. Adapun hambatan yang ditemui sebagian besar berada pada proses penghimpunan. Dimana partisipasi dari seluruh unit kerja di lingkup KKP belum maksimal dalam pendataan dan penyerahan koleksi local content kepada Perpustakaan KKP. Hal ini terjadi karena belum adanya peraturan yang rinci dan jelas terkait penghimpunan koleksi local content di lingkup KKP.

Hambatan lain yang ditemukan adalah pada proses pendayagunaan koleksi local content. Dimana Perpustakaan KKP telah memulai proyek knowledge repository sebagai wadah dalam untuk menyebarluaskan koleksi local content, pada akhir tahun 2015 , namun keberlanjutan dari proyek tersebut perlu diberi perhatian. Khususnya pada penyediaan perangkat keras dan perangkat lunak, serta sumber daya manusia di bidang teknologi informasi.

Kajian ini pada dasarnya masih bersifat luas. Oleh karena itu, perlu adanya kajian lanjutan yang lebih khusus dan detail serta metodologi yang lebih menyeluruh dan mengulas cakupan perpustakaan khusus instansi pemerintah yang lebih luas.

\section{DAFTAR PUSTAKA}

Earwage, A. S.-V. (2008). Institutional Repositories: Benefits and Challenges for Libraries. United States of America. Dipetik Oktober 20, 2016, dari http://arizona.openrepository.com/ arizona/handle/10150/106098

Indonesia. (n.d.). Undang-undang Republik Indonesia Nomor 43 Tahun 2007 tentang Perpustakaan. Jakarta.

Johnson, P. (2009). Fundamentals of Collection Development and Management 2nd ed. Chicago: American Library.

Liauw, T. T. (2005). Desa Informasi: Local Content Global Reach. Seminar of International Council on Archieves, Section on University and Research Institution Archieves, (pp. 6-9). East Lansing.

Setiawati, U. (n.d.). Pengembangan Local Content: Pengalaman di Perpustakaan UNIKOM. Retrieved November 13, 2016, from http:// elib.unikom.ac.id

Sulistyo-Basuki. (1991). Pengantar IImu Perpustakaan dan Informasi. Jakarta: Gramedia Pustaka Utama.

Wu, M. (2015, September/October). The Future of Institutional Repositories at Small Academic Institutions: Analysis and Insights. 21(9/10). 